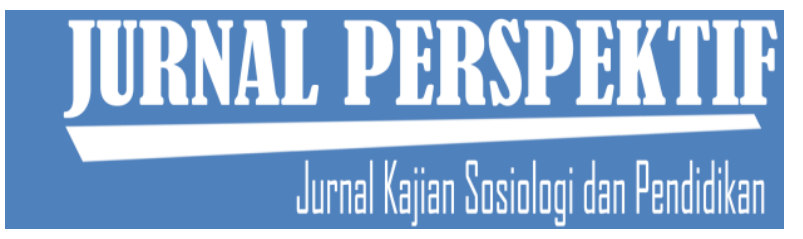

Jurnal Perspektif: Jurnal Kajian Sosiologi dan Pendidikan Vol. 2 No. 4 Tahun 2019

http://perspektif.ppj.unp.ac.id

Email: perspektif@ppj.unp.ac.id

ISSN: 2622-1748 (Online), 2684-902X (Print)

DOI: http://dx.doi.org/10.24036/perspektif.v2i4.159

\title{
Pola Interaksi Sosial Pedagang dengan Nelayan di Pasar Ikan Pantai Purus Padang Kecamatan Padang Barat
}

\author{
Merliya Merliya ${ }^{1}$, Ikhwan Ikhwan ${ }^{2}$ \\ ${ }^{1,2}$ Universitas Negeri Padang; Padang, Indonesia, \\ Email : merliya437@gmail.com, ichone.in@gmail.com
}

\begin{abstract}
Abstrak
Penelitian ini bertujuan untuk mengetahui pola interaksi sosial pedagang ikan di pasar ikan pantai Purus Padang Kecamatan padang Barat. Penelitian ini dianalisis menggunakan teori yang dikemukakan oleh James Scoot.Penelitian ini menggunakan pendekatan kualitatif dengan tipe studi kasus. Penelitian kualitatif ini menggunakan teknik pemilihan informan yaitu purposive sampling dengan jumlah informan yaitu 20 orang. Pengumpulan data dalam penelitian dilakukan dengan cara observasi, wawancara, dan studi dokumentasi yang dianalisis dengan teknik analisis data yang dikemukakan oleh Miles dan Huberman. Hasil penelitian menunjukan bahwa pola interaksi sosial pedagang dengan nelayan yaitu hubungan Patron-Klien.Hubungan patron-klien terjadi antara pedagang dengan nelayan pemilik kapal.Dimana yang bertindak sebagai patron yaitu pedagang, sedangkan yang menjadi klien yaitu nelayan, meskipun nelayan dalam hal ini sebagai pemilik kapal, namun hasil tangkapan yang sedikit yang disebabkan karena nelayan masih menggunakan alat tangkap tradisional membuat nelayan masih bergantung kepada pedagang. Hubungan patron-klien antara pedagang, dengan nelayan dapat dilihat dari dua aspek yaitu aspek sosial dan aspek ekonomi. Aspek sosial hubungan patron-klien diantaranya: hubungan nelayan dengan pedagang dekat, jarang terjadi konflik antar pedagang dengan nelayan, dan mengadakan arisan antar pedagang dengan nelayan. Sedangkan aspek ekonomi dari hubungan patron-klien antara pedagang dengan nelayan yaitu: sumber daya yang tidak seimbang antara pedagang dengan nelayan dan hubungan yang saling menguntungkan antara pedagang dengan nelayan.
\end{abstract}

Kata Kunci: Pola Interaksi, Pedagang, Nelayan

\begin{abstract}
This study aims to determine the pattern of social interaction of fish traders in the Purus Padang coastal fish market, West Padang District. This study was analyzed using the theory put forward by James Scoot. This study uses a qualitative approach to the type of case study. This qualitative research uses informant selection technique that is purposive sampling with 20 informants. Data collection in research is done by observation, interviews, and documentation studies that are analyzed by data analysis techniques proposed by Miles and Huberman. The results showed that the pattern of social interaction between traders and fishermen is the Patron-Client relationship. Patronclient relations occur between traders and boat fishermen. Where that acts as a patron is a trader, while those who become clients are fishermen. Even though fishermen in this case are boat owners, the small catch caused by fishermen still using traditional fishing gear makes fishermen still dependent on traders. Patron-client relations between traders, and fishermen can be seen from two aspects, namely social aspects and economic aspects. The social aspects of the patron-client relationship include: the relationship between fishermen and close traders, rarely conflicts between traders and fishermen, and holding social gatherings between traders and fishermen. While the economic aspects of the patron-client relationship between traders and fishermen are: unbalanced resources between traders and fishermen and a mutually beneficial relationship between traders and fishermen.
\end{abstract}

Keywords: Interaction Pattern, Traders, Fishermen 


\section{Pendahuluan}

Kehidupan manusia tidak terlepas dari proses interaksi. Interaksi merupakan hubungan timbal balik antar individu, maupun dengan kelompok. Menurut Yoseph S Roucek interaksi merupakan suatu proses yang sifatnya timbal balik dan mempunyai pengaruh terhadap perilaku dan pihak-pihak yang bersangkutan melalui kontak langsung, melalui berita yang didengar, ataupun melalui surat kabar, (Soejono Soekanto, 1990). Selain itu Daniel J. Gilin dan Gilin juga mengungkapkan bahwa interaksi merupakan hubungan-hubungan sosial yang dinamis, yang menyangkut individu dengan individu, individu dengan kelompok, dan kelompok dengan kelompok, (Soejono Soekanto, 1990).Interaksi antar individu memberikan pengaruh, rangsangan atau stimulus kepada individu lainnya.

Interaksi sosial tidak terlepas dari adanya syarat dalam berinteraksi. Adapun syarat interaksi sosial yaitu adanya kontak sosial dan komunikasi. Kontak sosial merupakan usaha pendekatan pertemuan fisik dan rohaniah. Kontak sosial ini dapat bersifat primer (face to face) dan bersifat sekunder (melalui perantara). Kontak sosial juga bersifat positif seperti kerjasama dan bersifat negatif seperti pertentangan atau konflik atau sama sekali tidak menghasilkan interaksi sosial. Sedangkan komunikasi merupakan usaha penyampaian informasi kepada manusia lainnya, tanpa adanya komunikasi tidak akan terjadi interaksi sosial. Dalam komunikasi sering muncul berbagai macam perbedaan penafsiran terhadap makna suatu tingkah laku orang lain akibat perbedaan konteks sosialnya. Komunikasi dalam prosesnya menggunakan isyarat-isyarat sederhana adalah bentuk paling dasar dan penting dalam komunikasi.

Interaksi dalam prosesnya memerlukan orang lain agar tercapainya tujuan dalam proses interaksi. Sama halnya dengan interaksi yang dilakukan oleh pedagang ikan. Pedagang ikan untuk mendapatkan ikan membutuhkan nelayan, sedangkan nelayan membutuhkan pedagang untuk mendapatkan uang. Dalam keterbatasan akses jaringan sosial bagi nelayan membutuhkan orang lain yang berada diluar komunitasnya, (Amiruddin, 2014) yaitu pedagang. Pedagang merupakan orang atau institusi yang memperjualbelikan produk atau barang, kepada konsumen baik secara langsung maupun tidak langsung, (Damsar, 1997). Nelayan merupakan orang yang melakukan kegiatan penangkapan ikan di laut.Nelayan terdiri dari dua yaitu nelayan besar dan nelayan kecil.Nelayan besar yaitu nelayan yang memiliki kapal dan hasil tangkapan yang didapatkan besar.Sedangkan nelayan kecil adalah orang yang mata pencahariannya melakukan penangkapan ikan untuk memenuhi kebutuhan hidup seharihari yang menggunakan kapal perikanan paling besar berukuran 5 GT (gross ton), (Satria Arif, 2015). Ditjen perikanan (2000) mendefenisikan nelayan sebagai orang yang secara aktif melakukan pekerjaan dalam operasi penangkapan ikan (binatang air lainnya, tanaman air), (Satria Arif, 2015). Mulyadi (2007) menyatakan bahwa nelayan memiliki ketergantungan yang tinggi terhadap teknologi penangkapan, (Hidayat, Fuad Kusuma, 2016). Artinya nelayan sangat bergantung kepada peralatan yang digunakan dalam penangkapan ikan. Selain itu kemampuan nelayan dalam meningkatkan pendapatan, menghidupi keluarga, dan membangun masa depan yang lebih baik sangat rendah, (Pakpahan, Helena Tatcher, 2006). Begitupun dengan interaksi antara pedagang ikan, dan nelayan terjadi karena adanya saling 
ketergantungan antara satu dengan yang lainnya. Ketergantungan antara pedagang, dengan nelayan tidak terlepas dari interaksi yang berkelanjutan.

Interaksi asosiatif dan disosiatif dapat ditemukan dalam proses interaksi yang dilakukan oleh pedagang ikan, dengan nelayan seperti yang terjadi di Taman Ikan Segar Puruih atau yang lebih dikenal dengan nama Pasar ikan. Pendirian Pasar ikan ini dilakukan oleh Pemeritah Kota Padang untuk menyatukan pedagang ikan yang terpencar menjadi satu tempat sehingga masyarakat mempunyai banyak pilihan untuk membeli ikan yang segar. Pasar ikan ini merupakan pemberian Dinas Perikanan dan Kelautan sebagai upaya dalam memperbaiki perekonomian pedagang ikan yang ada di Purus. Adapun perbedaan setelah adanya pasar ikan dapat dilihat dalam tabel berikut ini:

\section{Tabel 1. Perbedaan Sebelum dan Setelah Adanya Pasar Ikan}

\begin{tabular}{lll}
\hline \multirow{2}{*}{ No Aspek } & \multicolumn{3}{c}{ Perbedaan } \\
\cline { 2 - 4 } & \multicolumn{1}{c}{$\begin{array}{c}\text { Sebelum adanya taman ikan segar } \\
\text { Puruih }\end{array}$} & $\begin{array}{c}\text { Setelah adanya taman ikan } \\
\text { segar Puruih }\end{array}$ \\
\hline & $\begin{array}{l}\text { Dari segi tempat, sebelum adanya } \\
\text { taman ikan segar puruih para }\end{array}$ & $\begin{array}{l}\text { Setelah adanya taman ikan } \\
\text { segar puruih, para pedagang }\end{array}$ \\
& pedagang ikan biasanya berjualan & ikan ditempatkan secara \\
1. Tempat & memanjang pantai purus dan hanya & berkelompok dan diberikan \\
& & fasilitas untuk menunjang \\
& & para pedagang berjualan ikan \\
& & seperti kotak/ fiber, meja dan \\
& & lain-lain. \\
\hline
\end{tabular}

Pedagang mengalami kesulitan dalam mencari tempat berjualan karena banyaknya pengunjung atau wisatawan pantai. Jika hari hujan para

2. Pedagang pedagang tidak bisa berjualan ikan dikarenakan tidak adanya tempat.

Pedagang lebih mudah dalam menjual ikannya, apabila ikannya tidak habis pedagang tinggal memasukannya kedalam kotak/ fiber supaya ikannya tetap awet dan bisa dijual lagi esok hari.

Pedagang tidak khawatir lagi berdagang dalam kondisi cuaca yang buruk.

Sebelum adanya taman ikan segar puruih pembeli ikan kesulitan dalam memilih ikan yang harus dibeli karena

3. Pembeli pedagang ikan menjualnya secara terpisah-pisah.
Setelah adanya taman ikan segar puruih ini pembeli lebih mudah dalam memilih ikan segar yang diminatinya tanpa perlu berjalan jauh-jauh lagi untuk mendapatkan ikan yang diminati.

Sebelum adanya taman ikan segar puruih para penjual ikan berjualan disepanjang pantai sehingga bau amis ikan yang dijual oleh para pedagang mengganggu kenyaman wisatawan pantai.
Setelah adanya taman ikan segar puruih ini para pedagang sudah ditempatkan secara khusus, sehingga bau ikan tidak mengganggu wisatawan sehingga wisatawan bisa menikmati suasana pantai dengan 

nyaman.

\begin{tabular}{llll}
\hline & \multicolumn{2}{l}{ Sebelum adanya pasar ikan nelayan Setelah adanya taman ikan } \\
& mengalami kesulitan dalam segar puruih, nelayan lebih \\
5. Nelayan & memberikan hasil tangkapannya mudah memberikan hasil \\
& kepada pedagang dikarenakan tempat tangkapan, karena lokasi yang \\
& pedagang menjual jauh dari nelayan & dekat dengan nelayan. \\
\hline
\end{tabular}

Sumber: Observasi dan Wawancara Awal

Berdasarkan tabel di atas dapat dilihat kemudahan yang diperoleh oleh pedagang setelah berdirinya pasar ikan. Selain itu, tempat yang strategis di tepi pantai memberikan kemudahan dalam bertransaksi antara pedagang ikan dan nelayan. Pasar ikan memberikan ruang dalam berinteraksi bagi pedagang ikan, dengan nelayan. Pedagang ikan membutuhkan nelayan untuk mendapatkan ikan. Interaksi yang terjadi antara pedagang dengan nelayan dilatarbelakangi oleh kebutuhan yang sejalan. Interaksi sosial yang terjadi antar pedagang mengakibatkan satu dengan yang lain dapat memberi pengaruh dalam bersikap dan berperilaku dalam kegiatan ekonomi. Menurut Sanstrom dan Dunn (2014), interaksi juga dapat membangun kepercayaan antara kedua pihak, termasuk penjual dan pembeli, (Panggabean, 2017). Hal ini terjadi tidak terlepas dari proses interaksi yang berkelanjutan antara pedagang ikan, dengan nelayan sehingga terbentuk pola interaksi.

Penelitian ini bertujuan untuk mengetahui bagaimana pola interaksi sosial antara pedagang dengan nelayan yang berada di pasar ikan pantai Purus Padang Kecamatan Padang Barat.Penelitian ini dianalisis menggunakan teori yang dikemukakan oleh James Scoot yaitu Patron-Klien. Scoot (1972) mengatakan bahwa hubungan patron-klien adalah suatu kasus khusus hubungan antara dua orang yang sebagian besar melibatkan ekonominya (patron) menggunakan pengaruh dan sumber daya yang dimilikinya untuk memberikan perlindungan atau keuntungan kepada orang yang lebih rendah kedudukannya (klien), yang pada gilirannya membalas pemberian tersebit dengan memberikan dukungan yang umum dan bantuan , termasuk jasa-jasa pribadi kepada patron, (Muhammad Firzan, 2017).Lebih jauh Scoot mengemukakan bahwa hubungan patrronase memiliki ciri-ciri tertentu yang membedakannya dengan hubugan sosial yang lain, yakni : (a) adanya ketimpangan dalam pertukaran, (b) bersifat tatap muka (c) bersifat luas dan meluas, (Ikhwan dan Afrifa Khaidir, 2003).

\section{Metode Penelitian}

Penelitian ini merupakan penelitian kualitatif dengan menggunakan tipe studi kasus. Penelitian kualitatif adalah metode penelitian yang berlandaskan pada filsafat postpositivisme, digunakan untuk meneliti pada kondisi obyek yang alamiah, dimana peneliti adalah sebagai instrument kunci, teknik pengumpulan data dilakukan secara triangulasi (gabungan), analisis data bersifat induktif/kualitatif, dan hasil penelitian kualitatif lebih menekankan makna dari pada generalisasi, (Sugiyono, 2009). Sementara itu Rosady Ruslan menyatakan bahwa metode penelitian kualitatif adalah metode penelitian yang menghasilkan data abstrak atau tidak terukur tetapi menjelaskan dengan kata-kata, (Azheharie, 2015). Tipe 
penelitian studi kasus yaitu studi yang dilakukan karena ingin mendapatkan pemahaman yang lebih baik tentang suatu kasus. Subjek dalam penelitian ini adalah pedagang dan nelayan. Teknik pengumpulan data dalam penelitian ini menggunakan teknik purposive sampling atau sampel bertujuan. Jumlah informan dalam penelitian ini adalah 20 informan yang terdiri dari 10 nelayan dan 10 pedagang. Teknik yang digunakan dalam pengumpulan data pada penelitian ini yaitu observasi (pengamatan), wawancara dan studi dokumentasi.Observasi merupakan teknik yang menggunakan pengamatan atau penginderaan langsung terhadap suatu benda, kondisi, situasi, dan proses atau perilaku, (Idrus Muhammad, 2009) Wawancara yang dilakukan adalah wawancara mendalam ( in-depth Interview), yang berfungsi untuk mendapatkan data lisan yang lebih dalam memaknai pola interaksi yang terjadi dalam hubungan pedagang ikan dengan dengan nelayan. Dokumentasi menurut Syaodih (2000) merupakan suatu teknik pengumpulan data dengan menghimpun dan menganalisis dokumendokumen, baik dokumen tertulis, gambar maupun elektronik, (Idrus Muhammad, 2009). Penelitian mengenai pola interaksi antara pedagang dengan nelayan dianalisis menggunakan teknik analisis data dari Miles dan Huberman (reduksi data, penyajian data, dan penarikan kesimpulan).

\section{Hasil dan Pembahasan}

Hubungan Patron-Klien disetiap daerah berbeda-beda, hubungan patron-klien yang terjadi di daerah Purus Padang Kecamatan Padang Barat yaitu hubungan pedagang dengan nelayan pemilik kapal. Meskipun disini nelayan sebagai pemilik kapal namun hasil tangkapannya tidak maksimal, karena masih menggunakan alat tangkap tradisional seperti mata pancing, jaring, dan pukat sehingga nelayan masih bergantung kepada pedagang demi kelangsungan hidup nelayan yang berada di Purus. Salah satu strategi adaptasi dalam mengatasi kesulitan ekonomi yang dihadapi nelayan adalah menjalin hubungan social, (Sinaga, 2015). Hubungan yang dimaksud adalah hubungan patron-klien. Legg (1983) dalam Najib (1999) mengungkapkan bahwa tata hubungan patron-lien umumnya berkaitan dengan: (1) hubungan diantara pelaku yang menguasai sumber daya tidak sama; (2) hubungan khusus yang merupakan hubungan pribadi dan mengandung keakraban; (3) hubungan yang didasarkan atas saling menguntungkan. Selain itu ikatan patron-klien juga terjadi karena setiap pihak, baik patron maupun klien memiliki penguasaan sumber daya dan kemampuan yang tidak sama,(Priyatna, 2011). Posisi klien adalah seorang individu yang telah memasuki sebuah hubungan pertukaran yang tidak setara dimana ia tidak dapat membalas sepenuhnya dengan materi, (Rokhmah, 2015)

Hubungan patron-klien antara pedagang dengan nelayan dapat dilihat dari aspek sosial dan aspek ekonomi.

\section{Aspek Sosial}

\section{Hubungan pedagang dengan nelayan dekat}

Salah satu yang mencirikan hubungan Patron-klien adalah adanya hubungan yang dekat. Dimana patron mengenal kliennya. Hal yang sama juga terjadi pada hubungan pedagang dengan nelayan yang berada di Purus.

\section{Jarang terjadi Konflik antar Pedagang dengan Nelayan}

Hubungan patron-klien ditandai dengan adanya jarangnya terjadi konflik antara patron dengan klien dikarenakan hubungan yang merekan jalani saling menguntungkan antara kedua belah pihak. 


\section{Mengadakan Arisan}

Mengadakan arisan atau Julo-julo dalam hubungan pedagang dengan nelayan menandakan bahwa hubungan tersebut terdapat saling kepercayaan antar pedagang dengan nelayan

\section{Aspek Ekonomi}

\section{Sumber Daya yang Tidak Seimbang}

Hubungan Patron-klien ditandai dengan adanya ketimpangan. Ketimpangan ini dapat dirasakan oleh klien, dimana klien merasa dirugikan dan patron diuntungkan. Namun klien dalam hal ini tidak bisa berbuat apa-apa melainkan tetap pasrah kepada keadaan dikarenakan patron memiliki peran yang besar dalam kehidupan klien. Hubungan yang serupa juga dirasakan oleh nelayan yang berada di Purus. Meskipun nelayan merupakan nelayan pemilik namun tidak menjamin bahwa kehidupan nelayan baik. Nelayan pemilik kapal dengan alat tangkap yang sederhana tidak menjanjikan kehidupan yang lebih baik. Nelayan harus mendapatkan pertolongan dari pedagang (agennya) untuk kelangsungan hidup nelayan.

\section{Hubungan yang Saling Menguntungkan}

Hubungan Patron-Klien didasarkan karena kedua belah pihak merasa diuntungkan, baik bagi patron maupun pada klien. Patron mengambil keuntungan kepada klien dengan cara menguasai sumber daya yang dimiliki oleh klien, sehingga klien mempunyai kewajiban kepada patron. Sebaliknya klien akan mendapatkan keuntungan dari patron yaitu jaminan bagi kelangsungan hidup klien

Teori hubungan patron-klien yang dikemukakan oleh James Scoot yang mengargumentasikan bahwa hubungan patron-klien memiliki ciri-ciri yaitu akumulasi status kehormatan bagi diri patron. Ciri-ciri Patron-Klien dikemukakan oleh Scoot yang membedakannya dengan hubungan sosial lainnya. Pertama, yaitu terdapatnya ketidaksamaan(inequality) dalam pertukaran; kedua, adanya sifat tatap muka (face to face), dan ketiga, sifatnya luwes dan meluas (diffuse Flexibelity). Menguraikan ciri pertama Scoot mengatakan terdapat ketimpangan pertukaran: "disini terdapat ketidakseimbangan dalam pertukaran antara dua pasangan, yang mencerminkan perbedaan dalam kekayaan, kekuasaan, dan kedudukan.

Nelayan dalam menjalankan kehidupannya memilih menjalin hubungan dengan patron. Nelayan menjain hubungan dengan pedagang dikarenakan ketergantungan nelayan kepada pedagang sangat tinggi, begitupun sebaliknya pedagang juga membutuhkan nelayan dalam pemenuhan dagangannya. Adapun hubungan patron-klien yang terdapat dalam hubungan antara pedagang dengan nelayan yang berada di Purus Kecamatan Padang Barat yaitu dilihat dari aspek ekonomi dan aspek sosial:

\section{Hubungan pedagang dengan nelayan dekat.}

Patron mengenal klien merupakan hubungan yang digambarkan oleh Scott mengenai hubungan patron-klien. Hal ini juga terjadi pada hubungan antara pedagang dengan nelayan yang berada di Purus Kecamatan Padang Barat. Dimana Pedagang dengan nelayan hubungannya dekat. Pedagang mengetaui bagaimana kehidupan nelayan, begitupun sebaliknya. Hubungan yang terjalin antara pedagang dengan nelayan sudah dilakukan selama bertahun-tahun sehingga pedagang maupun nelayan sudah memahami kepribadian patron maupun kliennya.

\section{Jarang terjadi konflik antara pedagang dengan nelayan.}


Penyebab dari jarangnya terjadi konflik antar pedagang dengan nelayan Purus Kecamatan Padang Barat ini adalah karena hubungan antara pedagang dengan nelayan sudah dekat sehingga pedagng memahami kondisi nelayan. Ini merupakan dampak dari hubungan patron-klien yang membuat seseorang merasa membutuhkan orang lain sehingga meminimalisir terjadinya konflik. Walaupun terjadi konflik antara pedagang dengan nelayan, hal itu disebabkan karena adanya kesalah pahaman dalam bertransaksi. Konflik yang terjadi antara pedagang dengan nelayan hanya berskala kecil, dan sangat jarang terjadi konflik yang berskala besar.

\section{Mengadakan Arisan.}

Mengadakan arisan antara pedagang dengan nelayan merupak suatu bentuk dalam menjalin keakraban antara pedagang dengan nelayan. membangun kepercayaan antara pedagang dengan nelayan dan untuk melihat karakter seseorang dalam melakukan hubungan dengan orang lain. Apakah seseorang tersebut bisa diberikan kepercayaan atau tidak itu akan terlihat dari kejujurannya dalam membayar arisan atau julo-julo.

\section{Sumber daya yang tidak seimbang.}

Hubungan patron-klien yang dikemukakan oleh Scoot yaitu adanya penguasaan sumber daya yang tidak seimbang antara patron dengan klien. Patron memeliki sumber daya yang lebih banyak dari klien dan juga kekuasaan, sehingga klien harus mengikuti keinginan patron karena sudah terikat dengan patron. Hal yang sama juga terjadi pada pedagang dengan nelayan Purus Kecamatan Padang Barat. Dimana yang bertindak sebagai patron adalah pedagang sedangkan yang menjadi klien yaitu nelayan. Meskipun nelayan disini adalah nelayan pemilik tetapi nelayan Purus masih tetap saja bergantung kepada patronnya yaitu pedagang. Hal ini dikarenakan nelayan Purus masih tradisional yaitu dengan menggunakan alat tangkap yang sederhana seperti mata pancing, jarring dan pukat.

\section{Hubungan yang dijalin saling menguntungkan.}

Scoot mengatakan bahwa hubungan patron-klien terjadi karena adanya hubungan yang saling menguntungkan kedua belah pihak. Patron mengambil keuntungan dari klien dan klien mendapatkan keuntungan dari patron. Hal ini juga terjadi pada hubungan antara pedagang dengan nelayan yang berada di Purus Kecamatan Padang Barat. Pedagang mengambil keuntungan dari nelayan dengan cara memebeli ikan kepada nelayan dan membuat nelayan merasa terikat dengan pedagang, sehingga nelayan selalu memberikan hasil tangkapannya kepada pedagang yang sama. Sedangkan keuntungan yang didapat oleh nelayan yaitu nelayan mendapat jaminan bagi kelangsungan hidup nelayan tersebut. Caranya yaitu nelayan bisa mendapatkan pinjaman dari pedagang. Pinjaman ini dapat dikembalikan dengan cara mencicil apabila nelayan mendapatkan banyak ikan. Hal ini merupakan konsekuensi dari adanya hubungan patron-klien, dimana kedua pihak sama-sama diuntungkan dalam setiap proses transaksi, meskipun keuntungan yang diperoleh tidak sama.

\section{Kesimpulan}

Berdasarkan hasil penelitian tentang pola interaksi sosial pedagang ikan di pasar ikan pantai Purus Padang Kecamatan Padang Barat, dapat diambil kesimpulannya sebagai berikut: hubungan yang terjadi antara pedagang dengan nelayan yaitu hubungan patron-klient. Hubungan patron-klien dapat dilihat dari aspek sosial dan aspek ekonomi. Aspek sosial dari hubungan patron-klien ini adalah hubungan pedagang dengan nelayan dekat, dekat dalam 
artian pedagang mengenal nelayannya dan mengetahui bagaimana kehidupan nelayannya. Begitupun sebaliknya nelayan juga mengenal pedagangnya (agen). Hubungan patron-klien juga ditandai dengan jarang terjadi konflik antara pedagang dengan nelayan. Penyebab jarangnya terjadi konflik antar pedagang dengan nelayan adalah masing-masing sudah memahami kehidupan. Hal ini imbasan dari hubungan yang dekat antara patron-klien sehingga menyebabkan jarang terjadinya konflik antara pedagang dengan nelayan. selain itu bentuk aspek sosial dari hubungan antara pedagang dengan nelayan yaitu mengadakan arisan. Hal ini dilakukan untuk membangun kejujuran dan kepercayaan anatara pedagang dengan nelayan sehingga terciptanya hubungan yang saling menguntungkan kedua belah pihak.

Sedangkan aspek ekonomi yaitu adanya sumber daya yang tidak seimbang antara patron dengan klien, dimana patron mempunyai kekuatan untuk menekan klien. Pedagang mempunyai kekuasan dalam menentukan harga terhadap nelayan, dan nelayan hanya bisa mengikuti kehendak pedagang karena merasa ketergantungan terhadap pedagang. Selain itu aspek ekonomi yang lainnya yaitu hubungan antara patron dank lien didasarkan karena kedua pihak merasa saling diuntungkan sehingga terjalin suatu ikatan yang membuat patron bergantung pada klien dan sebaliknya klien mengharapkan patron dalam kelangsungan kehidupannya.

\section{Daftar Pustaka}

Amiruddin, S. (2014). Jaringan Sosial Pemasaran pada Komunitas Nelayan Tradisional Banten. Komunitas, 6,(1), 106-115.

Azheharie, S. (2015). Pola Komunikasi Antara Pedagang dan Pembeli di Desa Pare, Kampung Inggris Kediri. Komunikiasi, 7,(2), 207-223.

Damsar. (1997). Sosiologi Ekonomi. Jakarta: PT Raja Grafindo Persada.

Hidayat, fuad Kusuma, dan P. H. P. (2016). Pola Interaksi dan Perilaku Pertukaran Kelompok

Nelayan TPI Udang Jaya Desa Keburuhan Kecamatan Ngombol, Purworejo. Analisa Sosiologi, 5,(1), 51-61.

Idrus Muhammad. (2009). Metode Penelitian Sosial. Jakarta: Erlangga.

ikhwan dan Africa khaidir. (2003). Interaksi Pendatang dengan Masyarakat Asli Ekonomi di Kabupaten Mentawai. Padang: Universitas Negeri Padang.

Muhammad Firzan. (2017). Hubungan Patron-Klien Masyarakat Nelayan di Kampung Tanjung Limau Kleurahan Gunung Elai Kecamatan Bontang Utara Kota Bontang. EJournal Sosiatri-Sosiologi.

Pakpahan, Helena Tatcher, dkk. (2006). Hubungan Motivasi Kerja dengan Perilaku Nelayan pada Usaha Perikanan Tangkap. Penyuluhan, 2,(1), 26-34.

Panggabean, A. P. (2017). Kualitas Interaksi Sosial antara Penjual dan Pembeli di Taman Pintar Book Store Yogyakarta. Psikologi, 2,(2), 106-118.

Priyatna, F. N. dan S. (2011). Pola Pemanfaatan Sumber Daya, Subsistensi dan Pola Hubungan Ptron-Klien Masyarakat Nelayan Danau Tempe, Sulawesi Selatan. Matematika, Saint, Dan Teknologi, 12,(1), 37-45.

Rokhmah, F. dan P. H. (2015). Hubungan Patron-Klien antara Pemilik dan Penarik Perahu Tambang di Daerah Pagesangan-Surabaya. Paradigma, 3,(2), 1-5.

Satria Arif. (2015). Pengantar Sosiologi Masyarakat Pesisir. Jakarta: Yayasan Pustaka Obor Indonesia.

Sinaga, H. dk. (2015). Pola Hubungan Patron-Klien pada Komunitas Nelayan di Kelurahan Malabro Kecamatan Teluk Segara Kota Bengkulu. AGRISEP, 15,(2), 167-176.

Soejono Soekanto. (1990). Sosiologi Suatu Pengantar. Jakarta: PT Raja Grafindo Persada.

Sugiyono. (2009). Metode Penelitian Kualitatif $R \&$ D. Bandung: Alfabet. 
Merliya, Ikhwan

Pola Interaksi Sosial Pedagang dengan Nelayan di Pasar Ikan Pantai Purus Padang Kecamatan Padang Barat 